\title{
СЕСТРИНСЬКА МОДЕЛЬ КОМУНІКАТИВНО-ПРОФІЛАКТИЧНОГО КОНСУЛЬТУВАННЯ СІМ’Ї ІЗ ЙОДОДЕФІЦИТНОГО РЕГІОНУ
}

\author{
Сестринська модель комунікативно- \\ профрілактичного консультування сім'ї із \\ йододефріцитного регіону

\section{М. І. Бачу} \\ Буковинський державний медичний університет, \\ м. Чернівці
}

Резюме. Медична сестра покликана використовувати знання, вміння і навички в організації оптимальної комунікаційної взаємодії із сім'єю та надавати необхідну консультативну допомогу всім ії членам.

Мета дослідження - розробити сестринську модель комунікативно-профрілактичного консультування сімей із йододефіцитних регіонів проживання.

Матеріали і методи. Проведено анкетування 117 медичних сестер лікувально-профрілактичних закладів Чернівецької області з метою виявлення знань щодо впливу йододефріциту. Анонімна анкета містить 14 питань, спрямованих на отримання відомостей про думку респондентів щодо медичних і соціальних наслідків йододесріциту, про групи ризику, про існуючі методи профрілактики.

Результати. Більшість (105 із 117 опитаних, 89,6 \%) знає про наявний десріцит йоду в Чернівецькій області та його наслідки на організм. Однак 12 (10,3\%) не змогли визначити критичні групи впливу, виокремити найбільш вагомий негативний вплив на окремі групи населення. ми запропонували сестринську модель комунікативнопрофрілактичного консультування сім'ї, яка визначає стратегічний (забезпечення усіх категорій населення комплексною, об'єктивною інфрормацією з питань йододефріциту) та тактичний (інсрормування усіх цільових груп населення з питань, які стосуються профрілактики йододефріцитних станів) напрямки. Комплексна модель комунікативної діяльності медичної сестри визначає завдання та фрункції; рівень, об'єкт, інструмент впливу; форми реалізації; необхідні ресурси; моніторине і оцінку. Консультування сім'ї повинно пройти три фрази: позиція лідера, спостереження за взаємодією між членами сім"ї, вплив на структуру взаємодії.

Висновки. Запропонована модель дозволить забезпечити якісну діяльність медичної сестри та підвищити ефективність проорілактики розвитку йододефріцитних станів.

Ключові слова: медсестринство; модель комінукативно-профрілактичного консультування; йододесріцит.
Nursing model of communicative-preventive counseling of a family from the iodine-deficiency region

M. I. Bachu

Bukovinian State Medical University, Chernivtsi

e-mail: t.sorokman@gmal.com

Summary. The nurse is called to use knowledge, skills and abilities in the organization of optimal communication with the family and to provide the necessary counseling to all its members.

The aim of the study - to develop a nursing model of communicative and preventive counseling for families from iodine-deficient regions of residence.

Materials and Methods. A survey of 117 nurses of medical and preventive institutions of Chernivtsi region was conducted in order to identify knowledge about the effects of iodine deficiency. The anonymous questionnaire contains 14 questions aimed at obtaining information on respondents' opinions on the medical and social consequences of iodine deficiency, risk groups, existing prevention methods.

Results. The majority (105 out of 117 respondents, $89.6 \%)$ know about the existing iodine deficiency in Chernivtsi region and its effects on the body. However, $12(10.3 \%)$ failed to identify critical groups of influence, to identify the most significant negative impact on certain groups. We have proposed a nursing model of communicative and preventive family counseling, which defines strategic (providing all categories of the population with comprehensive, objective information on iodine deficiency) and tactical (informing all target groups on issues related to the prevention of iodine deficiency) areas. The complex model of communicative activity of the nurse defines tasks and functions; level, object, tool of influence; forms of implementation; necessary resources; monitoring and evaluation. Family counseling should go through three phases: the position of the leader, monitoring the interaction between family members, the impact on the structure of interaction.

Conclusions. The proposed model will ensure the quality of work the nurse and increase the effectiveness of prevention of iodine deficiency.

Key words: nursing; model of communicative-preventive counseling; iodine deficiency. 


\section{ВСТУП}

Медсестринство - складова частина системи охорони здоров'я, що володіє значними кадровими ресурсами та реальними потенційними можливостями для задоволення потреб населення [1]. Негативна динаміка медико-демографрічних показників населення України разом зі складною соціально-економічною ситуацією вимагає пошуку нових методів надання медичної допомоги, що дають можливість підвищити її якість без додаткових матеріальних витрат [2]. Одним із основних шляхів для вирішення поставлених проблем $€$ розвиток медсестринства [3, 4].

Партнерство лікаря і медсестри полягає у тому, що лікар надає пацієнтові лікарську допомогу, а медсестра - сестринську допомогу, працюючи в рамках мультипрофресійної команди орахівців охорони здоров'я для підвищення якості медичної допомоги на усіх рівнях системи охорони здоров'я [5]. При створенні моделі сестринської справи необхідно враховувати необхідність орієнтованості на пацієнта, а не на хворобу. Компонентами сестринської моделі є пацієнт як об'єкт діяльності сестринського персоналу, джерело проблем пацієнта, мета та завдання сестринської допомоги, способи надання сестринської допомоги, оцінка якості та результатів надання сестринської допомоги. У професійній діяльності фрахівця 3 медсестринства особливу роль відіграє комунікація 3 пацієнтами та їхніми родичами [6]. Окреслюється проблема підготовки майбутніх медичних сестер до комунікаційного консультування сім"ї.

Уже декілька десятиріч надзвичайні зусилля різних медичних ((Всесвітня організація охорони здоров'я, Організація Об'єднаних Націй, Дитячий Фонд ООН (ЮНІСЕФ), Міжнародна рада з контролю за йододефіцитними захворюваннями (МРКЙД3), lodine Global Network (IGN)) та громадських організацій спрямовані на елімінацію йододесіцитних захворювань у всьому світі [7, 8]. Спеціальна сесія Генеральної асамблеї ООН в Деклараціії дій «Світ, сприятливий для життя дітей» зобов'язала країни забезпечити вільний доступ населення до інорормації про захворювання, що виникають унаслідок нестачі йоду в організмі людини. Оскільки ліквідувати йодний дефріцит як природний френомен на певній місцевості неможливо, профрілактика йододефріцитних захворювань серед найуразливіших категорій населення, до яких відносяться діти, вагітні, матері-годувальниці, має проводитися на постійній основі [9]. Саме тому важливе значення має розробка та впровадження в практику сестринської моделі комунікативнопрофрілактичного консультування сімей із йододефріцитних регіонів проживання.

Мета дослідження - розробити сестринську модель комунікативно-профрілактичного консуль- тування сімей із йододефріцитних регіонів проживання.

\section{МАТЕРІАЛИ І МЕТОДИ}

Проведено анкетування 117 медичних сестер лікувально-профрілактичних закладів Чернівецької області з метою виявлення знань щодо впливу йододеоріциту. Анонімна анкета містить 14 питань, спрямованих на отримання відомостей про думку респондентів щодо ролі наслідків дефіциту йоду, медичних і соціальних наслідків йододефріциту, про групи ризику, про існуючі методи профрілактики.

\section{РЕЗУЛЬТАТИ Й ОБГОВОРЕННЯ}

Більшість (105 із 117 опитаних, 89,6 \%) знає про наявний десріцит йоду в Чернівецькій області та його наслідки на організм. Однак 12 (10,3 \%) не змогли визначити критичні групи впливу, виокремити найбільш вагомий негативний вплив на окремі групи населення. Наші попередні дослідження [10] встановили десіцит знань із проблеми йододесіциту як серед дитячого, так і дорослого населення. У зв'язку з цим ми запропонували сестринську модель комунікативно-профрілактичного консультування сім'ї, яка визначає стратегічний (забезпечення усіх категорій населення комплексною, об'єктивною інорормацією з питань йододефріциту) та тактичний (інформування усіх цільових груп населення 3 питань, які стосуються профрілактики йододефріцитних станів) напрямки. Комплексна модель комунікативної діяльності медичної сестри визначає завдання та функції; рівень, об'єкт, інструмент впливу; форми реалізації; необхідні ресурси; моніторинг і оцінку (рис.).

Основним об'єктом профрілактичного комунікативного впливу $є$ здорові особи, особи які мають фактори ризику розвитку захворювань та члени їх сімей. Особливим об'єктом комунікативного впливу $€$ члени організованих колективів, працівники органів місцевого самоврядування, центрів соціального захисту населення, керівники організацій, закладів, підприємств, соціальних служб. Представлення інфрормації може здійснюватися під час масових спортивних та культурних заходів; учнівській та студентській молоді під час навчального процесу, а також розповсюдження інорормаційних матеріалів через засоби масової інфрормації, волонтерів.

Ресурсне забезпечення здійснюється через підготовку медичних сестер до використання сучасних методів комунікацій у просресійній діяльності; забезпечення доступності до отримання консультативної допомоги. Для чого має бути передбачена частка робочого часу на нормативному рівні; наявність інформаційних матеріалів зміст та подача яких розрахована на різні цільові групи інорормаційного впливу.
Вісник медичних і біологічних досліджень Bulletin of Medical and Biological Research
$1(7), 2021$ 

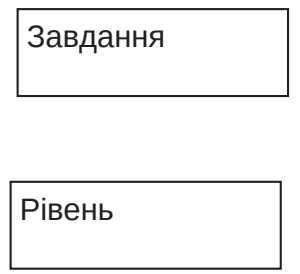

Об'єкт

Ресурсне забезпечення

Організаційне забезпечення основних

$$
\begin{aligned}
& \text { Види } \\
& \text { консультування }
\end{aligned}
$$

1.Забезпечити населення науковою інформацією 3 питань йододефіциту

2.Виділити об'єкти комунікативного та профілактичного впливу

1.Медичні сестри загальної практики - сімейної медицини

2.Медичні сестри дитячих поліклінік

3.Медичні сестри дДУ та навчальних закладів

\begin{tabular}{|l|lrr|}
\hline Здорові діти & Працівники органів місцевого & самовря- \\
Батьки & дування, центрів соціального & захисту \\
Вчителі & населення, керівники організацій, закладів, \\
Особи груп ризику & підприємств, соціальних служб \\
\hline
\end{tabular}

Підготовлена медична сестра

Сучасні методи комунікацій

Передбачена частка робочого часу медичної сестри на нормативному рівні

Інформаційні матеріали

Аналіз фракторів ризику серед різних верств населення Аналіз ефективності проведення профрілактичного консультування

Індивідуальне консультування під час відвідування лікаря

Консультування сім'ї

Рис. Сестринська модель комунікативного консультування.

Індивідуальне консультування дітей та їх батьків можливе під час відвідування лікаря з використанням методично-інорормаційних матеріалів: пам'ятки, буклети, плакати, муляжі, слайди, відео-, аудіо-матеріали. Консультування на рівні сім'ї здійснюється при індивідуальному відвідуванні сімейною медичною сестрою 3 використанням таких форм, як бесіди, консультації, поради, а також проведення занять із питань йодопрофрілактики при відвідуванні школи здоров'я. Консультування сім'ї повинно пройти три фрази. На першій сразі медична сестра займає позицію лідера. При цьому спостерігається етика спілкування та автономія сім'ї. Друга фраза - вивчення структури сім'ї, спостереження за взаємодією між членами сім'ї. Третя фраза консуль- тування сім'ї забезпечує вплив на структуру взаємодії, наголошуючи при цьому на лікувальному впливі позитивних емоцій на здоров'я членів сім'ї.

Важливою $€$ також методологія оцінки ефективності такої моделі. Запропоновані критерії оцінки, які можуть бути використані, наведені в таблиці.

Варто зазначити, що протягом останнього десятиліття увагу дослідники приділяють розробці моделей сестринської справи, орієнтованих на доказову сестринську практику [11, 12]. Європейське регіональне бюро ВООЗ визначило моделі, орієнтовані на основні фрункції сестринського персоналу, та підтвердило, що зміцнення й розвиток сестринської справи повинні підтримуватися за допомогою планування підготовки сестринських кадрів, створення

\begin{tabular}{|c|c|c|}
\hline \multicolumn{3}{|c|}{ Індикатор } \\
\hline структура & процес & результат \\
\hline $\begin{array}{l}\text { 1. Достатність інформаційних } \\
\text { матеріалів } \\
\text { 2. Показник охоплення навчанням } \\
\text { сімейних медичних сестер } \\
\text { 3. Наявність Школи здоров'я }\end{array}$ & $\begin{array}{l}\text { 1. Адміністративні рішення щодо орга- } \\
\text { нізації комунікативно-профрілактичного } \\
\text { консультування } \\
\text { 2. Показник охоплення населення про- } \\
\text { філактичними заходами } \\
\text { 3. Кількість членів сімей, які підготов- } \\
\text { лені до здійснення профрілактичних } \\
\text { заходів }\end{array}$ & $\begin{array}{l}\text { 1. Підвищення рівня поінформова- } \\
\text { ності щодо наслідків йододефіциту } \\
\text { 2. Збільшення кількості сімей, які } \\
\text { споживають йодовану сіль } \\
\text { 3. Позитивна оцінка населення щодо } \\
\text { результатів профрілактичних заходів }\end{array}$ \\
\hline
\end{tabular}

Таблиця. Критерії оцінки комунікативно-профрілактичного консультування 
нормативно-правової бази для розвитку сестринської справи. Запропонована модель консультування передбачає, насамперед, навчання, критерієм еорективності якого є підвищення рівня відкритості сім'ї, дружні стосунки між членами сім'ї, розуміння профрілактичних заходів задля збереження здоров'я, формування мотивації до зміни способу життя та підвищення прихильності до виконання рекомендацій.

\section{СПИСОК ЛІТЕРАТУРИ}

1. Абашник Н. М. Роль медичної сестри в Україні та у світі / Н. М. Абашник // Медсестринство. - 2019. № 4. - C. 7-10.

2. Яремчук О. В. Генезис сімейної медицини та перспективи його розвитку на теренах України. Інвестиції: практика та досвід / О. В. Яремчук. - 2018. - 24. C. $130-134$.

3. Петрущак О. М. Роль медичної сестри на сучасному етапі розвитку охорони здоров'я / О. М. Петрущак, І. Я. Криницька // Медсестринство. - 2017. - № 4. C. $48-50$.

4. Мельничук І. М. Теоретичні основи професійної підготовки фрахівців медсестринства / І. М. Мельничук // Науковий вісник Чернівецького університету. - 2015. Вип. 749. - С. 90-98.

5. Гудима А. А. Медсестринство в Україні XXI століття - погляд на проблему / А. А. Гудима // Медична освіта. - 2017. - № 2. - С. 120-123.

6. Брик О. І. Модель комунікаційного консультування сім'ї в роботі медичної сестри / О. І. Брик // Медссетринство. - 2017/ - № 4. - С. 59-61.

\section{REFERENCES}

1. Abashnyk NM. [The role of the nurse in Ukraine and in the world]. Medsestrynstvo. 2019;4: 7-10. Ukrainian.

2. Yaremchuk OV. [Genesis of family medicine and prospects of its development in Ukraine]. Investytsii: praktyka ta dosvid. 2018;24: 130-4. Ukrainian.

3. Petrushchak OM, Krynytska IYa. [The role of the nurse in the current stage of development of health care]. Medsestrynstvo. 2017;4: 48-50. Ukrainian.

4. Melnychuk IM. [Theoretical bases of professional training of nursing specialists. Scientific Bulletin of Chernivtsi University]. Naukovyi visnyk Chernivetskoho universytetu. 2015;749: 90-8. Ukrainian.

5. Gudima AA. [Nursing in Ukraine of the XXI century - a look at the problem]. Medychna osvita. 2017;2: 120-3. Ukrainian.

6. Brick OI. [A model of family communication counseling in the work of a nurse]. Medsestrynstvo. 2017;4: 59-61. Ukrainian.

7. WHO/ICCIDD/UNICEF. Assessment of iodine deficiency disorders and monitoring their elimination. 2nd Edition. Geneva: WHO, 2001.

\section{висновки}

Запровадження запропонованих інновацій дозволить забезпечити всі категорії населення та окремі групи комунікативного впливу комплексною інформацією з питань впливу йодного дефіциту на організм, що дозволить створити якісну діяльність медичної сестри та підвищити ефективність профрілактики розвитку йододефіцитних станів.

7. WHO/ICCIDD/UNICEF. Assessment of iodine deficiency disorders and monitoring their elimination. - 2nd Edition. - Geneva : WHO, 2001.

8. WHO: Draft action plan for the prevention and control of noncommunicable diseases for 2013-2020. http://apps. who.int/gb/ebwha/pdf_files/WHA66/A66_9-ru.pdf].

9. Маменко М. Е. Профрілактика йододесріцитних захворювань: що має знати і може зробити педіатр і лікар загальної практики? (клінічні рекомендації) / М. Е. Маменко // Сучасна педіатрія. - 2017. - № 2(82). - С. 68-76.

10. Сорокман Т. В. Роль медичної сестри в профрілактиці йододефіцитних захворювань у осіб різних вікових груп / Т. В. Сорокман, М. І. Бачу, О. В. Макарова // Клінічна та експериментальна патологія. - Т. 18, № 4 (70). - C. 85-91.

11. Scott P. A. What is nursing in the 21st century and what does the 21st century health system require of nursing? / P. A. Scott, A. Matthews, M. Kirwan // Nursing Philosophy. - 2013. - Vol. 15 (1). - P. 23-34.

12. P. Literature review : Why do we continue to lose our nurses? / P. Goodare // Australian Journal of Advanced Nursing. - 2017. - Vol. 34 (4). - P. 50-56.

8. WHO: Draft action plan for the prevention and control of noncommunicable diseases for 2013-2020. Retrieved from: http://apps.who.int/gb/ebwha/pdf_files/WHA66/A66_9ru.pdf].

9.Mamenko ME. [Prevention of iodine deficiency diseases: what should a pediatrician and a general practitioner know and can do? (Clinical recommendations)]. Suchasna pediatriia. 2017;2(82): 8-16. Ukrainian.

10.Sorokman TV, Bachu MI, Makarova OV. [The role of the nurse in the prevention of iodine deficiency diseases in people of different ages]. Klinichna ta eksperymentalna patolohiia. 18, 4(70): 85-91. Ukrainian.

11. Scott PA, Matthews A, Kirwan M. What is nursing in the 21st century and what does the 21st century health system require of nursing? Nursing Philosophy. 2013;15(1): 23-34.

12.Goodare P. Literature review: Why do we continue to lose our nurses? Australian Journal of Advanced Nursing. 2017;34(4): 50-6.

Отримано 09.02.21 